\title{
Empiricist Devotions: Science, Religion, and Poetry in Early Eighteenth-Century England (Review)
}

\section{ROBIN RUNIA \\ Xavier University of Louisiana}

Empiricist Devotions: Science, Religion, and Poetry in Early Eighteenth-Century

England, by Courtney Weiss Smith. Charlottesville and London: University of Virginia Press, 2016. Pp. 288. \$45. ISBN: 9780813938387.

I

n Empiricist Devotions, Courtney Weiss Smith offers an extended examination of the premise central to the work of Studies in Religion and the Enlightenment, that the long eighteenth century was not a secular age. Her specific focus applies this premise specifically to the world of science to conclude that natural philosophy in the early eighteenth century was not secular, and that, despite its empiricist methods, it was a science founded on Christian belief. She supports this conclusion by detailing the tendency of specific natural philosophers to engage in the practice of "occasional reflection," or, in other words, examining particulars of the natural world as representatives of Providential creation capable of providing humans moral and ethical direction. This practice, which Smith also alternately calls "occasional meditation” and "meditative empiricism" is defined by the process of analogizing human behavior according to the truths of nature God has provided as model or manual. With this observation, Smith goes on to insist on the shared methodology of poetry and natural philosophy in her examination of a number of important thinkers and writers from the period.

In Chapter 1, Smith recontextualizes Robert Boyle, detailing how his Occasional Reflections (1665) "brought together serious science and Protestant devotional techniques to forge an empiricist method for reading 'The Book of Nature'” (33). She also argues that just as Robert Hooke's work with microscopes led him to examine the minutia of natural phenomena, correlate, and hypothesize skeptical application, his "meditative empiricism” led him to examine, analogize, and reach provisional conclusions about Nature's suggestions for human behavior. The contemporary popularity of this kind of thinking and writing is suggested as evidence of a revolutionary power giving individuals the power to identify truths about the natural world, the moral world, and the God who made each.

Chapter 2, "Deus in Machina” provides a fascinating reading of the debate between Isaac Newton and G. W. Leibnitz. Smith returns to this debate in order to provide a compelling alternative reading of Newton's analogy of the clockwork world. Instead of seeing in Newton's analogy no role for an active God, Smith examines a variety of contemporary texts that insist on comparing Newton's observed natural laws to an active Providential force in the world. Examining works by George Berkeley and George Cheyne, as well as a poem by James Thomson, Smith argues that Newton's particular representation of God's corrective hand as clockmaker defined the empirical thought of natural scientists and poets alike. 
In the next two chapters, "Money, Meaning and a 'Foundation in Nature"” and "Empiricist Subjects, Providential Nature, and Social Contracts," Smith offers an exciting glimpse of the power of interdisciplinary work. She first refutes claims that the eighteenth century's path to modernization involved increasing abstraction and alienation of human society from the natural world. By comparing Tory and Whig writing on the coinage crisis closing the seventeenth century, Smith proves the tendency of thinkers, regardless of their political views to invoke "empirical devotion" to justify their arguments. Her subsequent analysis of it-narratives convincingly explains the power of the natural world to speak to humans and suggest moral truths. Similarly, her comparison between the social contract theorization of Lord Bolingbroke with that of Alexander Pope illustrates the shaping of poetic work by a belief in the power of Nature to inform human relations and communities. Following this with a comparison between the social contract theorization of John Locke and Daniel Defoe further insists on the need for today's scholars to nuance traditional narratives of Whig progressivism and Tory nostalgia through nuanced close reading of texts, poetic and otherwise.

The book's last chapter finally provides the sustained focus on poetry promised by its title. Here, Smith contextualizes georgic poetry according to its seventeenthcentury roots in the agricultural manual. She traces the transition of the agricultural manual tradition and its rejection of the imaginative or poetic elements of Virgil's Georgics to an eighteenth-century fusion of empirical meditation complete with personification, periphrases, and allusion. For Smith, georgic poetry evolved to become emblematic of the empirical meditative method. Observation of the natural world is used to analogize, in increasingly complex ways, human truths.

Ultimately, Smith provides close and compelling readings of texts often overlooked by scholars as well as alternative readings of texts often relegated to opposite disciplinary or ideological corners. Unfortunately, the book has a tendency to exaggerate some of these oppositions, failing to acknowledge the recent larger trend of the field to nuance and reconsider the narratives of modernization and secularization that had dominated eighteenth-century studies for so long. In addition, University of Virginia Press's use of endnotes, as opposed to footnotes, exacerbates this tendency, burying much of Smith's informed scholarly engagement between the end of her argument and her index. Nevertheless, this book provides an exemplary model of thoroughly reasoned, impeccably researched, and insightful close reading valuable to anyone interested in natural science, religion, and literature during the British Enlightenment. 